\title{
Sensitivity of salad greens (Lactuca sativa L. and Eruca sativa Mill.) exposed to crude extracts of toxic and non-toxic cyanobacteria
}

\author{
Bittencourt-Oliveira, MC. ${ }^{a, b, c *}$, Hereman, TC. ${ }^{a, b}$, Macedo-Silva, I. ${ }^{b}$, \\ Cordeiro-Araújo, MK..$^{a, c}$, Sasaki, FFC. ${ }^{a}$ and Dias, CTS. ${ }^{d}$

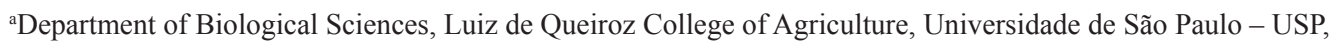 \\ Av. Pádua Dias, 11, São Dimas, CEP 13418-900, Piracicaba, SP, Brazil \\ 'Graduating Program on Biological Sciences, Universidade Estadual Paulista “Júlio de Mesquita Filho" - UNESP, \\ Av. 24-A, 1515, CEP 13506-900, Rio Claro, SP, Brazil \\ ${ }^{\mathrm{c}}$ Graduating Program on Botany, Universidade Federal Rural de Pernambuco - UFRPE, \\ Rua D. Manoel de Medeiros, S/N, Dois Irmãos, 52171-030, Recife, PE, Brazil \\ dDepartment of Exact Sciences, Luiz de Queiroz College of Agriculture, Universidade de São Paulo - USP, \\ Av. Pádua Dias, 11, São Dimas, CEP 13418-900, Piracicaba, SP, Brazil \\ *e-mail: mbitt@usp.br
}

Received: May 22, 2013 - Accepted: March 12, 2014 - Distributed: May 31, 2015

(With 3 figures)

\begin{abstract}
We evaluated the effect of crude extracts of the microcystin-producing $(\mathrm{MC}+)$ cyanobacteria Microcystis aeruginosa on seed germination and initial development of lettuce and arugula, at concentrations between $0.5 \mu \mathrm{g} . \mathrm{L}^{-1}$ and $100 \mu \mathrm{g} . \mathrm{L}^{-1}$ of MC-LR equivalent, and compared it to crude extracts of the same species without the toxin (MC-). Crude extracts of the cyanobacteria with $\mathrm{MC}(+)$ and without $\mathrm{MC}(-)$ caused different effects on seed germination and initial development of the salad green seedlings, lettuce being more sensitive to both extracts when compared to arugula. Crude extracts of M. aeruginosa $(\mathrm{MC}+)$ caused more evident effects on seed germination and initial development of both species of salad greens than $\mathrm{MC}-$. Concentrations of $75 \mu \mathrm{g} . \mathrm{L}^{-1}$ and $100 \mu \mathrm{g} . \mathrm{L}^{-1}$ of $\mathrm{MC}-\mathrm{LR}$ equivalent induced a greater occurrence of abnormal seedlings in lettuce, due to necrosis of the radicle and shortening of this organ in normal seedlings, as well as the reduction in total chlorophyll content and increase in the activity of the antioxidant enzyme peroxidase (POD). The MC- extract caused no harmful effects to seed germination and initial development of seedlings of arugula. However, in lettuce, it caused elevation of POD enzyme activity, decrease in seed germination at concentrations of $75 \mu \mathrm{g} . \mathrm{L}^{-1}$ (MC-75) and $100 \mu \mathrm{g} . \mathrm{L}^{-1}$ (MC-100), and shortening of the radicle length, suggesting that other compounds present in the cyanobacteria extracts contributed to this result. Crude extracts of M. aeruginosa (MC-) may contain other compounds, besides the cyanotoxins, capable of causing inhibitory or stimulatory effects on seed germination and initial development of salad green seedlings. Arugula was more sensitive to the crude extracts of M. aeruginosa $(\mathrm{MC}+)$ and $(\mathrm{MC}-)$ and to other possible compounds produced by the cyanobacteria.
\end{abstract}

Keywords: salad greens, irrigation, microcystin, productivity.

\section{Sensibilidade de hortaliças (Lactuca sativa L. e Eruca sativa Mill.) à exposição de extratos brutos de cianobactéria tóxica e não tóxica}

\begin{abstract}
Resumo
Analisamos os efeitos de extratos brutos da cianobactéria $M$. aeruginosa, produtora de microcistinas $(\mathrm{MC}+)$, na germinação de sementes e no desenvolvimento de plântulas de alface e rúcula, em concentrações de 0,5 a $100 \mu \mathrm{g} . \mathrm{L}^{-1} \mathrm{de}$ MC-LR equivalente e comparamos com extrato brutos da mesma espécie sem a toxina (MC-). Extratos brutos de cianobactérias com MC (+) e sem MC (-) causaram efeitos diferentes na germinação de sementes e desenvolvimento de plântulas de hortaliças, sendo que a alface apresentou maior sensibilidade a ambos os extratos comparando-se com a rúcula. Extratos brutos de $M$. aeruginosa $(\mathrm{MC}+)$ causaram efeitos mais evidentes sobre a germinação de sementes e desenvolvimento de plântulas de hortaliças do que os (MC-). Concentrações de 75 e $100 \mu \mathrm{g}$. $\mathrm{L}^{-1}$ de $\mathrm{MC}-\mathrm{LR}$ equivalente induziram maior ocorrência de plântulas anormais na alface devido ao aparecimento de necrose na radícula e seu encurtamento nas plântulas normais, bem como a redução no teor de clorofila total e aumento na atividade da enzima antioxidante peroxidase (POD). O extrato (MC-) não provocou efeitos inibitórios na germinação de sementes e desenvolvimento de plântulas para a rúcula, no entanto, provocou elevação da atividade da enzima POD, redução na germinação de sementes nas concentrações de 75 e $100 \mu \mathrm{g} . \mathrm{L}^{-1}$, e no comprimento da radícula na alface, sugerindo a
\end{abstract}


ação de outros compostos presentes nos extratos da cianobactéria. Extratos brutos de $M$. aeruginosa (MC-) podem conter outros compostos além de cianotoxinas capazes de provocar efeitos inibitórios ou estimulatórios na germinação de sementes e no desenvolvimento de plântulas de hortaliças. A rúcula apresentou menor sensibilidade aos extratos brutos de $M$. aeruginosa $(\mathrm{MC}+)$ e ( $\mathrm{MC}-$-) e outros possíveis compostos produzidos por estas cianobactérias.

Palavras-chave: hortaliças, irrigação, microcistina, produtividade.

\section{Introduction}

Salad green consumption in Brazil has increased over the last decade due to the adoption of healthier eating habits. Lettuce and arugula are among the most consumed salad greens mainly in salads (EMBRAPA and SEBRAE, 2010). Both can be grown in soil or hydroponically, and the quality and quantity of water used during their development is extremely important. It is a crucial factor to ensure the quality of the final product.

Several substances present in irrigation water, such as quantity of salts (Rhoades and Loveday, 1990), copper (Ahsan et al., 2007) and chromium (Prakash et al., 2004), can reduce the germination and development of seedlings, thus hampering production. Among these substances, the cyanotoxin microcystin (MC), a hepatotoxin that causes serious poisoning in animals, including humans (Carmichael, 1992; Yuan et al., 2006), can be included. In a previous study, Hereman and Bittencourt-Oliveira (2012), found in adult plants of lettuce accumulation concentrations of microcystin-LR equivalent above the recommended to the tolerable daily intake (TDI) for human consumption $\left(0.04 \mu \mathrm{g} . \mathrm{Kg}^{-1}\right)$ (WHO, 1998) when irrigated with crude extracts of toxic $M$. aeruginosa strain.

Microcystin is the most commonly detected cyanotoxin in bodies of fresh water, being produced mainly by $M$. aeruginosa (Kützing) Kützing. Its biosynthesis depends among others, on an enzymatic complex encoded by a gene cluster of microcystin synthetase ( $m c y$ ) (Tillett et al., 2000). Strains of $M$. aeruginosa containing these genes are potential producers of the toxin, and those that do not have the genes are incapable of producing MCs (Bittencourt-Oliveira et al., 2011).

Purified or crude extracts of microcystin not only reduce the germination of seeds of aquatic plants but also affect agricultural plants, such as peas (Pisum sativum L.), lentils (Lens esculenta Moench), maize (Zea mays L.) and wheat (Triticum durum L.) (Saqrane et al., 2008). Furthermore, the toxin interferes with the metabolism of the seedlings (Saqrane et al., 2009), causing necroses (Chen et al., 2004, M-Hamvas et al., 2003). However, it should be noted that cyanobacteria produce several compounds other than cyanotoxins (Leão et al., 2012), the function of which is still unknown, as are their effects on plants. Although on aquatic community some organisms may suffer direct effects due to contact with these different compounds (Leão et al., 2012).

Thus, our objective was to compare the effect of crude extract from a strain of microcystin-producing $M$. aeruginosa $(\mathrm{MC}+)$ and non-microcystin-producing $M$. aeruginosa (MC-) on seed germination and seedling development of lettuce (Lactuca sativa L.) and arugula (Eruca sativa Mill.).

\section{Material and Methods}

We used two strains of $M$. aeruginosa, one of which was microcystin-producing (BCCUSP232) $(\mathrm{MC}+)$ and the other non-producing (BBCUPS03) (MC-), according to Bittencourt-Oliveira (2003). The cultures were kept in a climatic chamber under controlled temperature $\left(22^{\circ} \mathrm{C}\right)$, photoperiod 14:10h (light: dark) and light intensity of $30 \mu \mathrm{mol} . \mathrm{m}^{-2} \cdot \mathrm{s}^{-1}$ (LI-COR photometer, mod. LI-250, with a spherical underwater sensor) in BG-11 medium, pH 7.4 (Rippka et al., 1979). At the end of the exponential growth phase, the cultures were centrifuged $\left(15 \mathrm{~min}, 20^{\circ} \mathrm{C}\right)$, frozen at $-80^{\circ} \mathrm{C}$ and lyophilized.

The qualitative and quantitative analysis of the strain BCCUSP232 compared to the MC-LR equivalent was performed using HPLC/MS, according to Bittencourt-Oliveira et al. (2005). Solutions with eight different concentrations $(0.5,2,5$, $10,25,50,75$ and $\left.100 \mu \mathrm{g} . \mathrm{L}^{-1}\right)$ of MC-LR equivalent were prepared using the lyophilized extract $(\mathrm{MC}+)$, re-suspended in deionized water and lysed by sonication $(5 \mathrm{~min}, 15 \mathrm{~W}$ and $22.5 \mathrm{kHz}$ ) in an ice bath. Cell lysis of the solutions was confirmed through observation under an optical microscope. The concentration used for the MC- extract corresponded to the dried mass of $\mathrm{MC}+$ extract used to obtain the concentrations of MC-LR equivalent. In the control (C), only deionized water was used.

Seeds of lettuce (L. sativa) and arugula (E. sativa) from Isla Sementes (Porto Alegre, state of Rio Grande do Sul) were used, cultivars Grand Rapids-TBR and Folha $L a r g a$, respectively. For each treatment, four replicates of 50 seeds were sown randomly in transparent plastic boxes using two sheets of blotting paper as substrate, which were saturated with $13 \mathrm{~mL}$ of solution from the treatments. The sheets were kept under constant conditions of light and temperature at $20^{\circ} \mathrm{C}$ for seven days. On the fourth day of evaluation, the sheets of filter paper for all treatments were moistened again with $1.0 \mathrm{~mL}$ of sterile deionized water. The plastic boxes were previously sterilized with $10 \%$ sodium hypochlorite solution, washed with distilled water, dried and kept under ultraviolet light $(\lambda=256 \mathrm{~nm})$ in a laminar flow for 45 min together with the sheets of blotting paper for sterilization. The climatic chamber was washed and disinfected using $37 \%$ formaldehyde solution.

The germination count was performed daily, using $2 \mathrm{~mm}$ in length of radicular protrusion as a criterion. After seven days of cultivation, the germination percentages and the production of normal seedlings were recorded, according to the Rules for Seed Analysis (Brasil, 1992). The percentage of normal seedlings was calculated from the total number of germinated seeds. 
Measurements of the length of the radicle and the shoot of five normal seedlings per replicate were taken randomly using a ruler calibrated in millimeters. These same seedlings were individually weighed using precision scales to obtain their fresh mass. Dry mass was obtained after being placed in paper bags and kept for $48 \mathrm{~h}$ in an oven at a constant temperature of $70^{\circ} \mathrm{C}$.

The cotyledons of three other normal seedlings, per replication, were cut, weighed using precision scales and immediately subjected to the extraction of chlorophyll. The remaining seedlings were frozen in liquid nitrogen for later extraction and analysis of the activity of peroxidase (POD).

The activity of peroxidase enzyme was determined by extraction using $0.3 \mathrm{~g}$ of crushed sample with $5 \mathrm{~mL}$ of potassium phosphate buffer $0.2 \mathrm{M}(\mathrm{pH}$ 6.7) and $1 \mathrm{mg}$ of polyvinylpyrrolidone (PVP). Next, the homogenate was centrifuged at $10,000 \mathrm{~g}$ for $10 \mathrm{~min}$ at $4^{\circ} \mathrm{C}$, the supernatant being considered the enzyme extract. For quantification of enzyme activity, $0.5 \mathrm{~mL}$ of solution containing $20 \mathrm{mM}$ hydrogen peroxide and phosphate buffer $(0.2 \mathrm{M}, \mathrm{pH} 6.7)$ and $0.5 \mathrm{~mL}$ of solution containing $4 \mathrm{mM}$ aminoantipyrine and $10 \mathrm{mM}$ phenol were added to $1 \mathrm{~mL}$ of enzyme extract. The solution was incubated in a water bath at $30^{\circ} \mathrm{C}$ for $5 \mathrm{~min}$ and the enzymatic reaction was stopped by adding $2 \mathrm{~mL}$ of absolute ethyl alcohol. The reading was performed using a spectrophotometer at a wavelength of $505 \mathrm{~nm}$. Results were expressed as $\mu$ Moles of $\mathrm{H}_{2} \mathrm{O}_{2}$ decomposed $/ \mathrm{min} / \mathrm{g}$ of fresh weight.

The total chlorophyll content was obtained after extraction in darkness at $20^{\circ} \mathrm{C}$ for $48 \mathrm{~h}$ using $100 \% \mathrm{MeOH}$ and spectrophotometric determination of absorbance at $662 \mathrm{~nm}$ (chlorophyll $a$ ) and $645 \mathrm{~nm}$ (chlorophyll $b$ ). The content of chlorophyll $a+b$ was calculated according to Lichtenthaler (1987) and expressed as $\mu \mathrm{g}$ of pigment per gram of fresh mass $\left(\mu \mathrm{g} \cdot \mathrm{g}^{-1}\right)$.

The results were submitted to analysis of variance (ANOVA) with comparison of means by the Tukey and Dunnett tests at $5 \%$ probability level using the SAS program.

\section{Results}

The effects of the extracts were significantly different depending on the sensitivity of each salad green species tested, being lettuce the most affected in the presence of MC-LR equivalent. The percentage of germination of lettuce seeds was reduced at higher concentrations, both with $\mathrm{MC}(6 \%$ in $\mathrm{MC}+75$ and $10 \%$ in $\mathrm{MC}+100)$ and without the toxin (5\% in MC-75 and 7\% in MC-100). On the other hand, no treatment interfered with the germination of arugula (Figure 1a). Equally, abnormal seedlings were only observed in lettuce at concentrations of $75 \mu \mathrm{g} . \mathrm{L}^{-1}$ and $100 \mu \mathrm{g} . \mathrm{L}^{-1}$ of MC-LR equivalent (Figure 1b). At these concentrations, there was a high incidence $(\sim 85 \%)$ of seedlings with radicle necrosis (Figure 2), a symptom also observed when cultivated in crude extracts with $75 \mu \mathrm{g} . \mathrm{L}^{-1}(\mathrm{MC}-75)$ and $100 \mu \mathrm{g} . \mathrm{L}^{-1}$ (MC-100), but at lower percentages, $48.8 \%$ and $56 \%$, respectively.
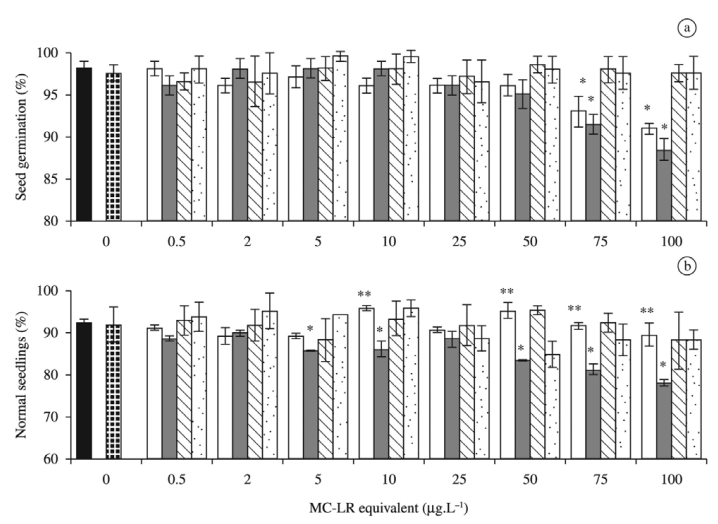

Figure 1. Percentage of seed germination (a) and normal seedlings (according to Brasil, 1992) (b) of lettuce and arugula. Control of lettuce ( $\square$ ); Control of arugula (曲). Application of crude extract without MC-LR equivalent (MC-) in lettuce $(\square)$ and arugula $(\mathbf{N})$. Application of crude extracts with MC-LR equivalent $(\mathrm{MC}+)$ in lettuce $(\square)$ and

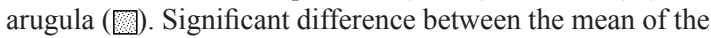
treatments with and without MC-LR equivalent using the Tukey test (**) and compared with the mean of the control using Dunnett's test $(*)$. Error bars represent standard deviation $(n=4)$.

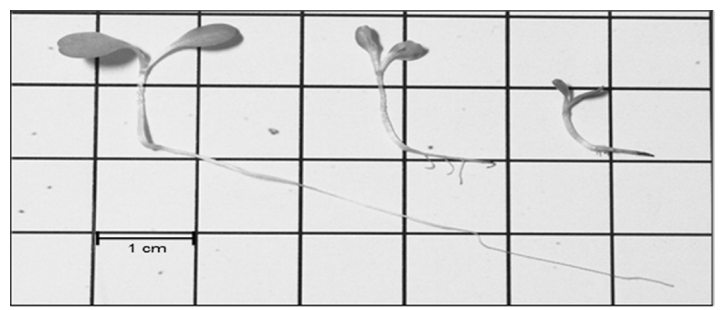

Figure 2. Lettuce seedlings. From left to right, normal seedling (according to Brasil, 1992) control (C), abnormal seedling (according to BRASIL, 1992) treated with $75 \mu \mathrm{g} . \mathrm{L}^{-1}$ of $\mathrm{MC}-\mathrm{LR}$ equivalent $(\mathrm{MC}+75)$, abnormal seedling treated with $100 \mu \mathrm{g} . \mathrm{L}^{-1}$ of $\mathrm{MC}-\mathrm{LR}$ equivalent $(\mathrm{MC}+100)$.

In lettuce, the length of the radicle was significantly reduced at $75 \mu \mathrm{g} . \mathrm{L}^{-1}$ and $100 \mu \mathrm{g} . \mathrm{L}^{-1}$ for both treatments ( $\mathrm{MC}+$ and $\mathrm{MC}-$ ), and the lowest values were found for the treatment with $\mathrm{MC}+$ (Figure 3a). In arugula, the lengths did not differ significantly. In general, the MC- extract stimulated the growth of the lettuce shoot. On the other hand, the $\mathrm{MC}+$ extract resulted in an increase in hypocotyl length at concentrations of $0.5 \mu \mathrm{g} . \mathrm{L}^{-1}$ to $50 \mu \mathrm{g} . \mathrm{L}^{-1}(\mathrm{MC}+0.5$ to $\mathrm{MC}+50)$. As for arugula, the treatment with $\mathrm{MC}+$ caused a reduction in the length of the shoots at concentrations of $25 \mu \mathrm{g} . \mathrm{L}^{-1}$ to $100 \mu \mathrm{g} . \mathrm{L}^{-1}$ (Figure 3b).

Only lettuce showed a significant increase in fresh mass in MC-75 and MC-100 and in MC+10. The dry mass increased in MC-100 (Table 1). The chlorophyll content was only reduced in lettuce to $24 \%$ in $\mathrm{MC}+50$ and $\mathrm{MC}+75$, reaching $30 \%$ reduction in $\mathrm{MC}+100$ (Table 2). There was an increase in peroxidase activity during the 

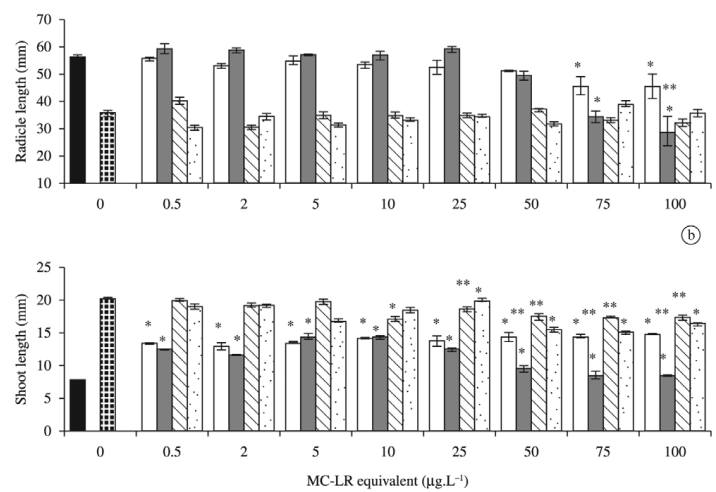

Figure 3. Length of the radicle (a) and shoot (b) of lettuce

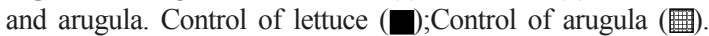
Application of crude extract without MC-LR equivalent (MC-) in lettuce $(\square)$ and arugula ( $\mathbf{N})$. Application of crude extracts with MC-LR equivalent (MC+) in lettuce ( $\square$ ) and arugula ( $\square$ ). Significant difference between the mean of the treatments with and without MC-LR equivalent using the Tukey test (**) and compared with the mean of the control using Dunnett's test (*). Error bars represent standard deviation $(n=4)$. seedlings development of arugula and lettuce (seedlings after 7 days of exposure) in treatments with $\mathrm{MC}+$ and MC- with no dose-dependent standard (Table 2).

\section{Discussion}

The difference in sensitivity to MC found in this study has already been observed for other plant species (Saqrane et al., 2009) and even for strains of the same species (Pflugmacher et al., 2007). Saqrane et al. (2008) observed a germination of $74.7 \%$ for lentils (Lens esculenta), and only 3\% germination for peas (Pisum sativum), when exposed to $11,600 \mu \mathrm{g} . \mathrm{L}^{-1}$ of MC-LR. In the present study, a concentration a thousand times less of $\mathrm{MC}-\mathrm{LR}$ equivalent caused a $10 \%$ reduction in germination of lettuce, $3 \%$ more than the extract without the toxin.

For lettuce, concentrations of $75 \mu \mathrm{g} . \mathrm{L}^{-1}$ of $\mathrm{MC}-\mathrm{LR}$ equivalent and over were sufficient to affect the development of seedlings, causing abnormalities such as necrosis and reduced radicle growth. The presence of reactive oxygen species (ROS) may contribute to necrosis, because it causes apoptosis (Huang et al., 2008). However, not only

Table 1. Values of fresh and dry mass $(\mathrm{mg})$ in seedlings of lettuce and arugula after seven days of exposure to $\mathrm{MC}+$ and MC- treatments at concentrations of $0.5,2,5,10,25,50,75$ and $100 \mu \mathrm{g} . \mathrm{L}^{-1}$ of MC-LR equivalent. MC+: crude extract with MC-LR equivalent.

\begin{tabular}{llllllllc}
\hline & \multicolumn{4}{c}{ MC } & \multicolumn{3}{c}{ lettuce } & \multicolumn{2}{c}{ arugula } & \multicolumn{2}{c}{ lettuce } & \multicolumn{2}{c}{ arugula } \\
\cline { 2 - 10 } & \multicolumn{1}{c}{ MC- } & MC+ & MC- & MC+ & MC- & MC+ & MC- & MC+ \\
\hline $\mathrm{C}$ & $13.3 \pm 0.61$ & $13.3 \pm 0.61$ & $40.2 \pm 7.4$ & $40.2 \pm 7.4$ & $0.72 \pm 0.05$ & $0.72 \pm 0.05$ & $6.25 \pm 0.58$ & $6.25 \pm 0.58$ \\
0.5 & $14.3 \pm 0.08$ & $14.7 \pm 0.11$ & $42.2 \pm 12.5$ & $41.9 \pm 9.7$ & $0.74 \pm 0.02$ & $0.72 \pm 0.01$ & $5.35 \pm 0.39$ & $5.33 \pm 0.80$ \\
2 & $14.1 \pm 0.62$ & $15.0 \pm 0.21$ & $39.3 \pm 1.3$ & $42.3 \pm 5.6$ & $0.79 \pm 0.03$ & $0.71 \pm 0.01$ & $4.68 \pm 0.67^{*}$ & $6.15 \pm 1.00$ \\
5 & $14.9 \pm 0.54$ & $14.5 \pm 0.05$ & $31.9 \pm 6.0$ & $37.7 \pm 0.9$ & $0.79 \pm 0.01$ & $0.71 \pm 0.04$ & $4.90 \pm 0.36$ & $4.95 \pm 0.75$ \\
10 & $14.3 \pm 0.47$ & $15.5 \pm 0.03^{*}$ & $37.0 \pm 6.4$ & $37.6 \pm 5.8$ & $0.71 \pm 0.04$ & $0.79 \pm 0.03$ & $5.10 \pm 1.02$ & $4.75 \pm 0.76$ \\
25 & $14,3 \pm 0,11$ & $14.4 \pm 0.64$ & $36.6 \pm 2.7$ & $39.3 \pm 5.1$ & $0.77 \pm 0.02$ & $0.74 \pm 0.04$ & $4.83 \pm 0.87$ & $5.00 \pm 0.78$ \\
50 & $14.4 \pm 0.49$ & $14.2 \pm 0.71$ & $39.8 \pm 3.6$ & $32.9 \pm 1.9$ & $0.76 \pm 0.06$ & $0.70 \pm 0.07$ & $5.40 \pm 0.40$ & $4.23 \pm 0.25^{*}$ \\
75 & $15.7 \pm 0.34^{*}$ & $14.1 \pm 0.44$ & $37.7 \pm 3.4$ & $39.6 \pm 4.7$ & $0.80 \pm 0.06$ & $0.69 \pm 0.03$ & $4.70 \pm 0.41$ & $5.10 \pm 0.54$ \\
100 & $17.7 \pm 0.45^{*}$ & $13.4 \pm 0.57$ & $35.2 \pm 7.1$ & $47.8 \pm 9.9$ & $0.90 \pm 0.05^{*}$ & $0.67 \pm 0.03$ & $4.85 \pm 0.87$ & $5.18 \pm 0.74$ \\
\hline
\end{tabular}

*Significant difference $(\mathrm{p}<0.05)$ compared to the control using Dunnett's test. MC-: crude extract without MC-LR equivalent. C: Control. Mean \pm standard deviation $(n=4)$.

Table 2. Chlorophyll $\mathrm{a}+\mathrm{b}\left(\mu \mathrm{g} . \mathrm{g}^{-1}\right)$ and peroxidase activity ( $\mu$ moles $\mathrm{H}_{2} \mathrm{O}_{2}$ decomposed.min ${ }^{-1} \cdot \mathrm{g}^{-1}$ ) in seedlings of lettuce and arugula after seven days of exposure to the treatments at concentrations of $0.5,2,5,10,25,50,75$ and $100 \mu \mathrm{g} . \mathrm{L}^{-1}$ of MC-LR equivalent.

\begin{tabular}{|c|c|c|c|c|c|c|c|c|}
\hline \multirow{3}{*}{ MC } & \multicolumn{4}{|c|}{ Chlorophyll $a+b$} & \multicolumn{4}{|c|}{ Peroxidase } \\
\hline & \multicolumn{2}{|c|}{ lettuce } & \multicolumn{2}{|c|}{ arugula } & \multicolumn{2}{|c|}{ lettuce } & \multicolumn{2}{|c|}{ arugula } \\
\hline & MC- & $\mathrm{MC}+$ & MC- & $\mathrm{MC}+$ & $\mathrm{MC}-$ & $\mathrm{MC}+$ & MC- & $\mathrm{MC}+$ \\
\hline $\mathrm{C}$ & $182.9 \pm 3.0$ & $182.9 \pm 3.0$ & $580.2 \pm 24.2$ & $580.2 \pm 24.2$ & $2.47 \pm 0.10$ & $2.47 \pm 0.10$ & $0.61 \pm 0.08$ & $0.61 \pm 0.08$ \\
\hline 0.5 & $203.7 \pm 8.9$ & $187.3 \pm 3.4$ & $615.7 \pm 74.8$ & $516.9 \pm 143.9$ & $3.93 \pm 0.20 *$ & $3.66 \pm 0.15^{*}$ & $0.35 \pm 0.01 *$ & $0.51 \pm 0.02 *$ \\
\hline 2 & $191.4 \pm 5.4$ & $176.0 \pm 10.4$ & $442.7 \pm 111.5$ & $582.5 \pm 74.6$ & $4.23 \pm 0.20 *$ & $3.55 \pm 0.07$ & $0.38 \pm 0.04^{*}$ & $0.67 \pm 0.02$ \\
\hline 5 & $159.1 \pm 5.4$ & $167.3 \pm 13.3$ & $632.9 \pm 67.0$ & $439.8 \pm 49.8$ & & $3.39 \pm 0.17$ & $0.35 \pm 0.02 *$ & $0.73 \pm 0.07 *$ \\
\hline 10 & $162.9 \pm 9.8$ & $159.2 \pm 5.2$ & $510.3 \pm 89.1$ & & & $4.45 \pm 0.20 *$ & $0.46 \pm 0.04 *$ & $0.71 \pm 0.03 *$ \\
\hline 25 & $150.0 \pm 4.3$ & $144.4 \pm 3.4$ & $627.8 \pm 107.3$ & & & $4.11 \pm 0.11^{*}$ & $0.43 \pm 0.01 *$ & $0.73 \pm 0.04^{*}$ \\
\hline 50 & $163.2 \pm 10.2$ & $138.4 \pm 9.9^{*}$ & $521.0 \pm 81.9$ & & $3.392 \pm 0.18$ & $4.19 \pm 0.19^{*}$ & $0.62 \pm 0.05$ & $0.61 \pm 0.02$ \\
\hline 75 & $162.2 \pm 8.5$ & $138.8 \pm 0.7^{*}$ & $535.7 \pm 72.9$ & & & $4.37 \pm 0.10 *$ & $0.67 \pm 0.03$ & $0.75 \pm 0.01 *$ \\
\hline 100 & $149.3 \pm 9.9$ & $127.8 \pm 7.8^{*}$ & $512.6 \pm 111.45$ & $476.4 \pm 33.1$ & $4.07 \pm 0.13^{*}$ & $7.67 \pm 0.54 *$ & $0.63 \pm 0.05$ & $0.79 \pm 0.16^{*}$ \\
\hline
\end{tabular}

*Significant difference $(\mathrm{p}<0.05)$ compared to the control using Dunnett's test. MC+: crude extract with MC-LR equivalent. $\mathrm{MC}-$ : crude extract without microcystins. C: Control. Mean \pm standard deviation $(n=4)$. 
did the MC-LR equivalent cause oxidative stress, but also the extract without MC (MC-) caused an increase in the activity of POD enzyme in our experiments.

In the present study, the results of oxidative stress in the seedlings development of lettuce when subjected to $\mathrm{MC}$ - treatments may represent effects of other compounds present in the extracts without MC-LR equivalent. There is evidence of several of these effects in the aquatic community. For example, Leão et al. (2012) demonstrated, in a laboratory study, that substances produced by the LEGE 05292 strain of Oscillatoria sp. (portoamides A, B, $\mathrm{C}$ and D) had inhibitory effects on the growth of species of cyanobacteria, diatoms and green algae.

Another important toxic compound produced by cyanobacteria is the lipopolysaccharide (LPS). This compound is considered to be produced by all cyanobacteria and is a structural constituent of the outer layers of the cell wall (Metcalf and Codd, 2004). Cyanobacterial LPS is attributed with a range of pathological effects in humans, from cutaneous signs and symptoms, gastrointestinal illness, respiratory disease, allergy, headache and fever (Stewart et al., 2006). On aquatic community, studies demonstrate that cyanobacterial LPS stimulate drinking in fish, the increased volume of water in the gut potentially increases the opportunity for uptake of toxins (including MC) from the water and promotes osmoregulatory imbalance on rainbow trout (Best et al., 2003). Thus, even a cyanobacteria non-cyanotoxins-producing may lead effects in other organisms.

The high concentrations of the extracts, especially $\mathrm{MC}+$, reduced radicle growth of normal lettuce seedlings. The effects of crude extract of non-microcystin-producing strains on seedlings development have, to our knowledge, been observed for the first time in this study. Concentrations of MC- extracts stimulated growth of the lettuce shoots, caused a reduction in the germination rate of seeds at higher concentrations (MC-75 and MC-100), and caused a reduction in the radicle length. Gehringer et al. (2003) found a greater reduction in the length of the radicle and the cotyledons of cress seedlings (Lepidium sativum) exposed to cell free extract containing $10 \mu \mathrm{g} . \mathrm{L}^{-1}$ of $\mathrm{MC}-\mathrm{LR}$ for the same concentration of purified toxin, indicating the presence, in the extract, of other organic compounds that intensify the shortening of the radicle and cotyledons.

Plants infected with MCs can be detoxified by a mechanism of conjugation with glutathione (Pflugmacher et al., 1998). As the molecule of MC is highly stable, and may persist in plant tissues until consumption, this process, in addition to fostering production of arugula, reduces the poisoning of consumers. However, the presence of MCs in lettuce exposed to the toxin was observed in adult plants (Crush et al., 2008; Hereman and Bittencourt-Oliveira, 2012), even at concentrations above those allowed by the World Health Organization (WHO, 1998).

According to Hereman and Bittencourt-Oliveira (2012), adult plants of lettuce may accumulate high concentrations of MC-LR equivalent after irrigation containing this toxin, exceeding the TDI of microcystins to the human consumption. On the other hand, adult plants of arugula (on the same experimental conditions) showed no microcystin accumulation (Macedo-Silva, 2011). These different results can indicate the most sensitivity of lettuce to MC-LR equivalent compared with the arugula in the current research, which can be related to the detoxification system of each species.

\section{Conclusions}

We found differences in sensitivity between species of salad greens tested, being arugula less sensitive than lettuce and the extract of microcystin-producing strain caused more harmful effects than the non-producing strain. The MC- extracts also affected the development of lettuce, although to a lesser extent than the $\mathrm{MC}+$, showing that other substances produced by cyanobacteria may also affect the development of plants. The use of irrigation water contaminated with MCs may exert a negative biochemical effect on the germination of lettuce seeds and in the metabolism of seedlings thereby reducing their productivity.

\section{Acknowledgements}

This research was supported by grants from FAPESP (2007/57508-5) and CNPq (301739/2011-0, 470198/2011-7).

\section{References}

AHSAN, N., LEE, D-G., LEE, S-H., KANG, KY., LEE, JJ., KIM, PJ., YOON, H-S., KIM, J-S. and LEE, B-H., 2007. Excess copper induced physiological and proteomic changes in germinating rice seeds. Chemosphere, vol. 67, no. 6, p. 1182-1193. http://dx.doi. org/10.1016/j.chemosphere.2006.10.075. PMid:17182080

BEST, JH., EDDY, FB. and CODD, GA., 2003. Effects of Microcystis cells, cell extracts and lipopolysaccharide on drinking and liver function in rainbow trout Oncorhynchus mykiss Walbaum. Aquatic Toxicology (Amsterdam, Netherlands), vol. 64, no. 4, p. 419-426. http://dx.doi.org/10.1016/S0166-445X(03)00105-X. PMid:12878412

BITTENCOURT-OLIVEIRA, MC., 2003. Detection of potential microcystin-producing cyanobacteria in Brazilian reservoirs with a mcyB molecular marker. Harmful Algae, vol. 2, no. 1, p. 51-60. http://dx.doi.org/10.1016/S1568-9883(03)00004-0.

BITTENCOURT-OLIVEIRA, MC., KUJBIDA, P., CARDOZO, KHM., CARVALHO, VM., MOURA, AN., COLEPICOLO, P. and PINTO, E., 2005. A novel rhythm of microcystin biosynthesis is described in the cyanobacterium Microcystis panniformis Komárek et al. Biochemical and Biophysical Research Communications, vol. 326, no. 3, p. 687-694.

BITTENCOURT-OLIVEIRA, MC., OLIVEIRA, MC. and PINTO, E., 2011. Diversity of microcystin-producing genotypes in Brazilian strains of Microcystis (Cyanobacteria). Brazilian Journal of Biology $=$ Revista Brasileira de Biologia, vol. 71, no. 1, p. 209-216.

BRASIL, 1992. Regras para análise de sementes. SNDA/ DNDV/ CLAV/ Ministério da Agricultura e Reforma Agrária, Brasília. 
CARMICHAEL, WW., 1992. Cyanobacteria secondary metabolites - The Cyanotoxins. Journal of Applied Bacteriology, vol. 72, no. 6, p. 445-459.

CHEN, J., SONG, L., DAI, J., GAN, N. and LIU, Z., 2004. Effects of microcystins on the growth and the activity of superoxide dismutase and peroxidase of rape (Brassica napus L.) and rice (Oryza sativa L.). Toxicon, vol. 43, no. 4, p. 393-400.

CRUSH, JR., BRIGGS, LR., SPROSEN, JM. and NICHOLS, SN., 2008. Effect of irrigation with lake water containing microcystins on microcystin content and growth of ryegrass, clover, rape, and lettuce. Environmental Toxicology, vol. 23, p. 246-252.

Empresa Brasileira de Pesquisa Agropecuária - EMBRAPA and Serviço Brasileiro de Apoio às Micro e Pequenas Empresas SEBRAE, 2010. Catálogo Brasileiro De Hortaliças: saiba como plantar e aproveitar 50 das espécies mais comercializadas no País. Brasília: EMBRAPA/ SEBRAE. 59 p.

GEHRINGER, MM., KEWADA, V., COATES, N. and DOWNING, TG., 2003. The use of Lepidium sativum in a plant bioassay system for the detection of microcystin-LR. Toxicon, vol. 41, no. 7, p. 871-876. http://dx.doi.org/10.1016/S0041-0101(03)00049-7. PMid: 12782087

HEREMAN, TC. and BITTENCOURT-OLIVEIRA, MC., 2012. Bioaccumulation of microcystins in lettuce. Journal of Phycology, vol. 48, no. 6, p. 1535-1537. http://dx.doi.org/10.1111/jpy.12006.

HUANG, W., XING, W., LI, D. and LIU, Y., 2008. Microcystin-RR induced apoptosis in tobacco BY-2 suspension cells is mediated by reactive oxygen species and mitochondrial permeability transition pore status. Toxicology in Vitro : an International Journal Published in Association with BIBRA, vol. 22, no. 2, p. 328-337. http://dx.doi.org/10.1016/j.tiv.2007.09.018. PMid:18083002

LEÃO, PN., RAMOS, V., VALE, M., MACHADO, JP. and VASCONCELOS, VM., 2012. Microbial community changes elicited by exposure to cyanobacterial allelochemicals. Microbial Ecology, vol. 63, no. 1, p. 85-95. http://dx.doi.org/10.1007/ s00248-011-9939-z. PMid:21947429

LICHTENTHALER, HK., 1987. Chlorophylls and carotenoids: pigments of photosynthetic biomembranes. In PACKER, L. and DOUCE, R. (Eds). Plant Cell Membranes. London: Academic Press. p. 350-381. Methods in Enzimology, vol.148.

MACEDO-SILVA, I., 2011. Efeitos alelopáticos de microcistinas em rúcula (Eruca sativa Mill). Rio Claro: Instituto de Biociências, Universidade Estadual Paulista. 47 p. Masters Dissertation in Biological Sciences - Plant Biology.

METCALF, JS. and CODD, GA., 2004. Cyanobacterial toxins in the water environment: a review of current knowledge. Marlow: Foundation for Water Research. $36 \mathrm{p}$.

M-HAMVAS, M., MÁTHÉ, C., MOLNÁR, E., VASAS, G., GRIGORSZKY, I. and BORBELY, G., 2003. Microcystin-LR alters the growth, anthocyanin content and single-stranded DNase enzyme activities in Sinapis alba L seedlings. Aquatic Toxicology (Amsterdam, Netherlands), vol. 62, no. 1, p. 1-9. http://dx.doi. org/10.1016/S0166-445X(01)00273-9. PMid:12413789

PFLUGMACHER, S., AULHORN, M. and GRIMM, B., 2007. Influence of a cyanobacterial crude extract containing microcystin-
LR on the physiology and antioxidative defence systems of different spinach variants. The New Phytologist, vol. 175, no. 3, p. 482-489. http://dx.doi.org/10.1111/j.1469-8137.2007.02144.x. PMid: 17635223

PFLUGMACHER, S., WIEGAND, C., OBEREMM, A., BEATTIE, KA., KRAUSE, E., CODD, GA. and STEINBERG, CEW., 1998. Identification of an enzymatically formed glutathione conjugate of the cyanobacterial hepatotoxin microcystin-LR: the first step of detoxication. Biochimica et Biophysica Acta, vol. 1425, no. 3, p. 527-533. http://dx.doi.org/10.1016/S0304-4165(98)00107-X. PMid:9838216

PRAKASH, SM., YOGEETHA, MS. and PARAMA, VR., 2004. Effects irrigation water with chromium germination and growth of radish (Rhaphanus sativus L.). Nature. Environment and Pollution Technology, vol. 3, no. 1, p. 121-124.

RHOADES, JD. and LOVEDAY, JG., 1990. Salinity in irrigated agriculture. In STEWART, DR. and NIELSEN, DR. (Eds.). Irrigaton of agricultural crops. Madison: ASA/ CSSA/ SSSA. p.1089-1142. Agronomy, no. 30.

RIPPKA, R., DERUELLES, J., WATERBURY, JB., HERDMAN, M. and STANIER, RY., 1979. Generic assignments, strain histories and properties of pure cultures of cyanobacteria. Journal of General Microbiology, vol. 111, no. 1, p. 1-61. http://dx.doi. org/10.1099/00221287-111-1-1.

SAQRANE, S., EL GHAZALI, I., OUDRA, B., BOUARAB, L. and VASCONCELOS, V., 2008. Effects of cyanobacteria producing microcystins on seed germination and seedling growth of several agricultural plants. Journal of Environmental Science and Health. Part. B, Pesticides, Food Contaminants, and Agricultural Wastes, vol. 43, no. 5, p. 443-451. http://dx.doi. org/10.1080/03601230802062307. PMid:18576226

SAQRANE, S., OUAHID, Y., EL GHAZALI, I., OUDRA, B., BOUARAB, L. and DEL CAMPO, FF., 2009. Physiological changes in Triticum durum, Zea mays, Pisum sativum and Lens esculenta cultivars, caused by irrigation with water contaminated with microcystins: a laboratory experimental approach. Toxicon, vol. 53, no. 7-8, p. 786-796. http://dx.doi.org/10.1016/j. toxicon.2009.01.028. PMid:19470329

STEWART, I., SCHLUTER, P. and SHAW, G., 2006. Cyanobacterial lipopolysaccharides and human health - a review. Environmental Health: A Global Access Science Source, vol. 5. http://dx.doi. org/10.1186/1476-069X-5-7.

TILLETT, D., DITTMANN, E., ERHARD, M., VON DÖHREN, H., BÖRNER, T. and NEILAN, BA., 2000. Structural organization of microcystin biosynthesis in Microcystis aeruginosa PCC7806: an integrated peptide-polyketide synthetase system. Chemistry \& Biology, vol. 7, no. 10, p. 753-764. http://dx.doi.org/10.1016/ S1074-5521(00)00021-1. PMid:11033079

WORLD HEALTH ORGANIZATION - WHO, 1998. Cyanobacterial toxins: microcystin-LR guidelines for drinking-water quality. Geneva: World Health Organization. pp. 95-110.

YUAN, M., CARMICHAEL, WW. and HILBORN, ED., 2006. Microcystin analysis in human sera and liver from human fatalities in Caruaru, Brazil 1996. Toxicon, vol. 48, no. 6, p. 627-640. http://dx.doi.org/10.1016/j.toxicon.2006.07.031. PMid:16952386 